\title{
Political Culture Orientation of the Gayo Tribe in the Election of a District Head in 2017 in Lot Kala Village Kebayakan Sub District, Central Aceh District
}

\author{
Bobby Rahman ${ }^{1}$, Muhammad Bin Abubakar ${ }^{2}$, Teuku Muzaffarsyah ${ }^{3}$, Zulhilmi $^{4}$, Juni Ahyar ${ }^{5}$, \\ Eko Oktavian Ariga ${ }^{6}$ \\ ${ }^{1}$ Universitas Malikussaleh, Student Ph,D Universiti Malaysia Terengganu \\ ${ }^{2}$ Universitas Malikussaleh \\ ${ }^{3}$ Universitas Malikussaleh, Student Ph,D Universiti Malaysia Terengganu \\ ${ }^{4}$ Universitas Malikussaleh \\ ${ }^{5}$ Universitas Malikussaleh, Student Ph,D Universiti Malaysia Terengganu \\ ${ }^{6}$ Universitas Malikussaleh \\ *Corresponding author. Email: bobby.rahman@unimal.ac.id
}

\begin{abstract}
The political culture in a society in one area has a unique orientation towards the political system, this condition also applies to the Gayo tribe. The Gayo tribe is an ethnic group that inhabits the Gayo highlands in the central part of Aceh Province. The traditional territory of the Gayo tribe includes the districts of Bener Meriah, Aceh Tengah and Gayo Lues. In addition, the Gayo tribe also inhabits parts of Southeast Aceh, Aceh Tamiang and East Aceh. The Gayo tribe is Muslim and they are known to be devout in their religion and they use the Gayo language in their daily conversations. According to the community story, the Gayo tribe was formed by the Linge Kingdom, which was a Gayo kingdom in the Linge area of Central Aceh. This paper examines the political cultural orientation of the Gayo tribe in the election of a district head in 2017. The problem formulation of this paper are: First, how is the political culture of the Gayo tribe? Second, what is the orientation and political culture of the Gayo Tribe in the 2017 election of a district head in Lot Kala Village, Kebayaan District, Central Aceh Regency? The method used in this research was descriptive qualitative. From the results of the study, it is known that the Gayo people in Lot Kala village have a participant political culture because the Gayo tribe is very enthusiastic in choosing the Regent / Deputy Regent in the 2017 District Heads Election. Meanwhile, the political cultural orientation of the Gayo tribe in Lot Kala Village is classified as an affective orientation due to emotional ties and has a very close kinship in the customs owned by the Gayo tribe in Lot Kala Village. It can be seen from the Gayo tribe people who choose a life partner who comes from the native of Gayo tribe. The relationship between orientation and political culture in the Gayo Tribe tends to elect District head candidates who have the same ethnic background and tend to dislike District heads candidates who have affiliations and are paired with candidates from other tribes.
\end{abstract}

Keywords: Political Culture, Gayo Tribe, and District Heads Election

\section{INTRODUCTION}

The Regional Head Election (Pilkada) is a form of aspiration for the people of the Gayo Tribe to choose the head of the region. On February 15, 2017, elections were held in all regions of Indonesia including Aceh. In the election of the head of the region is divided into two elections, namely the election of governors and regents / mayors. In the election, it is certainly interesting that the attitude and behavior of the people in the face of the 2017 elections in Aceh, especially the city of Central Aceh Regency which is dominated by the Gayo people to choose the Regent / Deputy Regent of Central Aceh Regency.
Political culture is part of political life, although parties often view political culture as nothing more than conditions that color people's lives, without having any connection to either the political system or the political structure. Political culture is not taken into account at all in political processes (Afan Gaffar, 1999, p. 27). That assumption was widely used before the development of a self-basing approach to political culture. Political culture is a phenomenon in society that has an influence on political structures and systems.

In discussing the relationship between Orientation and Political Culture, Political Culture needs to be put forward because it concerns social disciplines and poitik science related to the 
phenomenon of society. Moreover, the political system can be reviewed as part of social science (Rusadi Sumitapura, 1998, p. 25). A particular political culture has always been attached to any society made up of a number of individuals living in both the traditional political system, as well as the modern political system. By examining the orientation of political culture we will recognize the traits that are pointed to test the process that continues and that changes in line with the process of development, change or social mutation.

Orientation is a behavior in an individual that sees or reviews an appropriate and correct person. This needs to be affirmed because an individual's attitude and orientation do not always manifest in his behavior (Ramlan Surbakti, 1992, p. 141). Such a political orientation is still in the state of thought of an abstract individual, but after that a political participation will be formed and the individual will behave politically that is in terms of voting in elections that are also referred to as political participation. This political orientation is also a decision that concerns and influences the political behavior of a person that will impact the choice of voters in choosing. Of course basically that choice is influenced by his orientation. In this study, it is still in the individual's mind that will be reviewed more deeply in terms of selecting candidates for Regent / Deputy Regent period 2017-2022 in Lot Kala Village Kebayakan District central aceh district in Pilkada 2017.

Human life in society has an important role in a country's political system. Man in his position as a social being, will always interact with other humans in an effort to realize his life needs. The needs of human life are not basic enough, such as eating, drinking, biological, clothing and boards (houses). More than that, it also includes the need for recognition of selfexistence and appreciation from others in the form of praise, the awarding of wages, status as a member of society, members of a particular political party and so on.

Every citizen, in his daily life almost always comes into contact with practical political aspects whether symbolized or not. In the process of implementation it can occur directly or indirectly with political practices. If indirectly, this is limited to hearing information, or news about political events that occur. It directly means that the person is involved in a particular political event. Political activities also enter the world of religion, economic and social activities, personal and social life at large. Thus, political culture directly influences political life and determines national decisions concerning the pattern of allocation of public sources

In the elections held in Central Aceh, there are 6 (six) pairs of candidates who will run as regents and bukpati representatives to run for government in Central Aceh Regency. From the 6th (six) there are 1 (one) couples who managed to win the vote from the election, namely from Drs.Shabella Abubakar Dan H.Firdaus, Skm who received $31.07 \%$ of the votes from all sub-districts located in Central Aceh Regency.

Table 1.1

The Name Of The Spouse Of The Regent/Vice Regent Of The Regency Of Central Aceh

\begin{tabular}{|c|c|}
\hline $\begin{array}{c}\text { Serial } \\
\text { number }\end{array}$ & The Name Of The Couple \\
\hline 1 & $\begin{array}{c}\text { H.Usman Nuzuly, SH.MH } \\
\text { M.Bukri, NS SH }\end{array}$ \\
\hline 2 & $\begin{array}{c}\text { Muchsin Hasan, M.SP } \\
\text { Drs. H. Taufik, MM }\end{array}$ \\
\hline 3 & $\begin{array}{c}\text { Alamsyah Mahmud } \\
\text { Gayo,SH.MM } \\
\text { Anda Suhada }\end{array}$ \\
\hline 4 & $\begin{array}{c}\text { Drs. H. Khairul Asmara } \\
\text { H. Zulfikar. Ab.SE }\end{array}$ \\
\hline 5 & $\begin{array}{c}\text { Drs.Shabella Abubakar d } \\
\text { H.Firdaus, SKM } \\
\text { Saiful Effendi } \\
\text { Nurhidayah, S.H }\end{array}$ \\
\hline 6 & \\
\hline
\end{tabular}

Although there are many tribes and ethnicities in Central Aceh Regency, it does not discourage the gayo indigenous people to be asusiased in choosing the leader they want. With strong fraternity ties and customs in central Aceh regency, gayo people make the election an event to choose a truly appropriate leader and can understand how the situation is in Central Aceh Regency.

The 2017-2022 Priode Regent/Deputy Regent election in Aceh, especially in Central Aceh Regency, is the most important part of the implementation of democracy in the democratic Central Aceh region. Elections are often interpreted as the embodiment of a democratic party for the people, where there is a process of voters (people) to choose the Leader who wants to be elected. PIlkada by the people is the implementation and embodiment of the sovereignty of the people in order to produce a democratic state government based on the Constitution of 1945 (Constitution 1945). The embodiment of this people's sovereignty by conducting elections directly to elect representatives of the people as a channel of the people's own aspirations. The implementation of the election using direct, general, confidential, free, honest, and fair principles. The embodiment of the sovereignty of the people is also written in Law No. 10 of 2008 stating elections. Therefore, this research will take a deeper look at "how gayo political cultural orientation was shaped in the 2017 elections in Lot Kala Village, Kebayakan District, Central Aceh Regency".

\section{LITERATURE REVIEW}

\subsection{Political Culture Theory}

According to Arief Budiman in Ismid Hadad (1979, p. 232), political culture is as a kind of idea embraced with many members of the community, not 
only about political issues, but also about aspects of life and society change. The changes mentioned above are mere technical changes, changes from an upward orientation to individualization or a change from feudal society to bourgeois society.

According to lmond and Verba in Ronald $\mathrm{H}$. Chilcote (2016, p. 29) defines political culture as a typical citizen orientation towards the political system and its diverse parts, and attitudes towards the role of citizens in the system. In other words, how to distribute specific orientation patterns towards political goals among the people of that nation. Furthermore, they state that citizens always identify themselves with symbols and state institutions based on their orientation. With that orientation, they also assess and question their place and role in the political system.

Political Culture is the interhuman relationship that is political reflecting the political culture in society. The political culture in people's lives with each other will vary. Political culture is a pattern of behavior of a society in the life of the state, the administration of the state, the politics of government, the law, customs, and norms of habit that are lively by all members of the community every day. Political culture can also be meant as a system of shared values of a society that has the awareness to participate in collective decision-making and public policy determination for the community as a whole. Political culture is the embodiment of political values embraced by a group of peoples, nations, or countries that are believed to be guidelines in carrying out state political activities.

\subsection{Orientasi Dalam Budaya Politik}

Orientation in political culture is divided into 3 traits ((Afan Gaffar, 1999, p. 99-100), namely::

1. Cognitive

It concerns the understanding and belief of the individual to the political system and its attributes, such as about the capital of the country, the head of state, the borders of the country, the currency used, and so on.

\section{Effective}

It concerns the emotional bonds that individuals have with the political system. So, it concerns the political system.effective

3. Evaluative

It concerns the capacity of individuals in order to provide an assessment of the current political system and how individuals play in it.

\subsection{Types of Political Culture}

Gabriel A. Almond and Bingham Powell in Simamora Sahat (1990. p.19) propose the classification of political culture as follows:

1. Parochial political culture, i.e. the political participation rate is very low, due to cognitive factors (e.g. relatively low levels of education).
2. The political culture of kaula or subject, i.e. the society in question has been relatively advanced but still passive.

3. The political culture of participants, namely political culture characterized by political awareness is very high.

Of the three components above used by the author to determine the political culture that is in the gayo community in Lot Kala Village Kebayakan subdistrict.

\section{RESEARCH METHOD}

In this study, researchers will use a qualitative approach that produces descriptive data analysis in the form of written or oral words from people and observed behavior, Moleong J lexy ( 2012, p. 4) Qualitative research types using scriptive-qualitative analysis methods, as well as qualitative exploratory. In qualitative research, in analyzing the data started from before the researchers went down the field that the initial data that the researchers found before the field jump directly to monitor the subject of the study the data was done analysis that will then be done merging and selection of data after the author finds the data in the field that then the author will present that then the researcher conducts a data check to be able to conclude the results of the study Data collection of this study will be done through observation activities or direct observation of the analysis object to dig relevant and important aspects as the basis for the analysis and interpretation to be carried out. This research in order to obtain valid or accurate data in addition to observation, data collection will be done through interviews.

\section{RESULT AND DISCUSSION}

\subsection{Political Orientation of Gayo Tribe in Pilkada} 2017

Political culture as a typical orientation in the community of a region towards the political system and its various parts and attitude towards the role of the people in the political system that occurs in the Gayo Tribe in Lot Kala Village is classified as effective, the Gayo tribe in Lot Kala village concerning the emotional bond struck by the Gayo Tribe in Lot Kala Village itself there is a politics that occurred during the Regional Head Election (Election) of Central Aceh Regency perode 20172022.

There is an emotional bond that the Gayo Tribe in Lot Kala Village can see from the people who choose a couple who are from the original Gayo Tribe who are from the same area of them and do not choose another partner because the other couple there is a coalition with a partner from another tribe, this is the attitude and political behavior of the Gayo Tribe in Lot Kala Village which remains at its establishment to seek to become a leader in Central Aceh.

Gayo Cultural Orientation is that gayo people are very enthusiastic about the election of the head of 
the region (Election) in the period 2017-2022 because the people like with the couple at the number 5 (five) because of the same tribe between the pairs of sequence number 5 (five) who are from the original Gayo tribe, Gayo people are also still wanting those from the original gayo tribe to be made Regents /Vice Regents 2017-2022 therefore they do not choose others because of other couples even though some are descendants of Gayo Asli but coalition with couples who are not from the Gayo Asli tribe.

The Gayo tribe in Lot Kala Village in its orientation still carries the heritage of their ancestors and still carries out the customs that apply to the Gayo community, Gayo community socialists are very high and participation in selecting regents / vice regents of Central Aceh period 2017-2022 is very high, and still in the order of political cultural elements, there is still a censory to follow the history carried out on their predecessors and the Gayo community which is now a modern society but still thick on customs and customs in the Gayo community.

From the data that has been obtained that the cultural orientation of the Gayo tribe in the 2017 election is the Gayo people in Lot Kala Village are classified in a political culture that participants namely the political culture marked with high awareness. Although the Gayo people tend to be pessimistic because the people consider it not a Democratic party but a people's party of a group, some Gayo people do not care about the democratic party but even though they are classified as pessimistic but they care and have a very high participation to participate in the process of electing the regional head (Election) of Central Aceh Regency period 2017-2022.

Based on data from the Central Aceh District Independent Electoral Commission (KIP) that the participation of the people of Lot Kala Village kebayakan sub-district is high where the number of voters who participated in the elections in Lot Kala Village, Kebayakan District of Central Aceh priode 2017-2022 is the total number of 980 voters, from the male party of 475 voters and from the female party of 505 voters, the number of voting users is 803 voters, men 396 total percentage $83.4 \%$ and women 407 total percentage $80.6 \%$, total golput (white group) $18.1 \%$, men $16.6 \%$ and women $19.4 \%$.

Gayo's cultural orientation is that participation in the community is only about $70 \%$ in the 2017 Election that means gayo community participation is very high with various aspects of the community from fishermen to farmers all gathered to give their voting rights and gayo community has begun to understand the importance of rights and obligations to choose leaders in accordance with the rules in the Gayo tribal community.

\subsection{Relationship between Gayo Political Culture in Pilakada 2017}

The relationship of political orientation that occurred to the Gayo Tribe in Lot Kala Village during the Central Aceh District Head Election period 20172022 has its own value in the Gayo people, namely that there are attitudes and behaviors of the people who participated to participate in the election of the Regent / Deputy Regent of Central Aceh Regency period 2017-2022, the community is enthusiastic to attend the election aimed at taking a stance and behavior orienatsinya choose a candidate for Regent /Deputy Regent of Central Aceh Regency 2017-2022 which comes from one of the candidates from the original Gayo Tribe. The Gayo People are less interested in other couples who are in coalition with the Tribe of the Gayo Tribe.

Gayo Cultural Orientation is that gayo people are very enthusiastic about the election of the head of the region (Election) in the period 2017-2022 because the people like with the couple at the number 5 (five) because of the same tribe between the pairs of sequence number 5 (five) who are from the original Gayo tribe, Gayo people are also still wanting to lead those from the original gayo tribe to be made Regents /Vice Regents 2017-2022 therefore they do not choose others because of other couples even though some are descendants of Gayo Asli but coalition with couples who are not from the Gayo Asli Tribe.

The community argues that the Cultural Orientation of the Gayo tribe in the leadership in gayo people's lives should come from the Gayo race because the Gayo people think it is very comfortable and peaceful when the leader is from the Gayo Tribe and the leader is completely aware of the religion and culture that is in the Gayo region, the Gayo people are very enthusiastic in selecting the Regent/Deputy Regent and no riots occurred in the regional head election (Election) of Central Aceh Regency period 2017-2022 yesterday.

\section{CONCLUSION}

Based on the results of the study can be concluded that political culture as a typical orientation in the community of a region towards the political system and various parts and attitude towards the role of the people in the political system that occurs in the Gayo Tribe in Lot Kala Village is classified as effective, Gayo tribe in Lot Kala Village concerning emotional bond struck by the Gayo people in Lot Kala Village itself there is politics that occurred in the Regional Election (Election) of Central Aceh Regency perode 2017-2022. There is an emotional bond that the Gayo tribe in Lot Kala village can see from the people who choose a partner who is from the original Gayo tribe who are from the same area as them and do not choose another partner because the other couple there is a coalition with a partner from another tribe, this is the attitude and political behavior of the Gayo Tribe in Lot Kala 
Village which remains in its establishment looking for a leader to become regent /vice regent in Central Aceh.

The relationship of political orientation that occurred to the Gayo Tribe in Lot Kala Village during the Central Aceh District Head Election period 2017-2022 has its own value in the Gayo people, namely that there are attitudes and behaviors of the people who participated to participate in the election of the Regent / Deputy Regent of Central Aceh Regency period 2017-2022, the community is enthusiastic to attend the election aimed at taking a stance and behavior orienatsinya choose a candidate for Regent /Deputy Regent of Central Aceh Regency 2017-2022 which comes from one of the candidates from the original Gayo Tribe. The Gayo People are less interested in other couples who are in coalition with tribes other than the Gayo Tribe.

\section{REFERENCES}

[1] Afan Gaffar, 1999, Politik Indonesia, Yogyakarta: Pustaka Pelajar.

[2] Rusadi Sumintapura, 1998, Sistem Politik Indonesia, Bandung: Sinar Baru.

[3] Ramlan Subakti. 1992, Memahami Ilmu Politik. Jakarta: PT. Gramedia Widiasarana Indonesia.
Lingkaran Survei Indonesia, "Faktor Etnis Dalam Pilkada",

[4]Ismid Hadad, 1979, Budaya Politik dan Keadilan Sosial Jakarta: LP3ES.

[5] Ronald H. Chilcote, 2016, Teori Perbandingan Politik, diterjemahkan oleh: A.H. Henry Sitanggang, SH. Jakarta: PT Raja Grafindo Persada.

[6] Bowen, John Richard, 1991,"Sumatran Politics and Poetics: Gayo History, 1900-1989", New Haven: Yale University Press

[7] Bungaran, 2011, “Gayo Merangkai Identitas: jakarata” Yayasan Obor Pustaka Indonesia.

[8] Teuku Muzaffarsyah, Zulhilmi, Bobby Rahman, M. Rizwan, Political Communications Strategy of "Success Team" in Regional Head Election: A Case Study of Bireuen, Aceh, In Proceedings of the 1st International Conference on Psychology (ICPsy 2019), Scitepress, 2020, p. 147-153. DOI: $10.5220 / 0009439101470153$

[9] Lexi J. Moleong, Metodologi Penelitian Kualitatif., PT. Remaja Rosdakarya, 1991 